\title{
Use of multispectral images to evaluate the efficacy of pre-emergent herbicides in peas under greenhouse conditions
}

\section{Uso de imágenes multiespectrales para la evaluación de la eficacia de herbicidas pre-emergentes en arveja, en condiciones de invernadero}

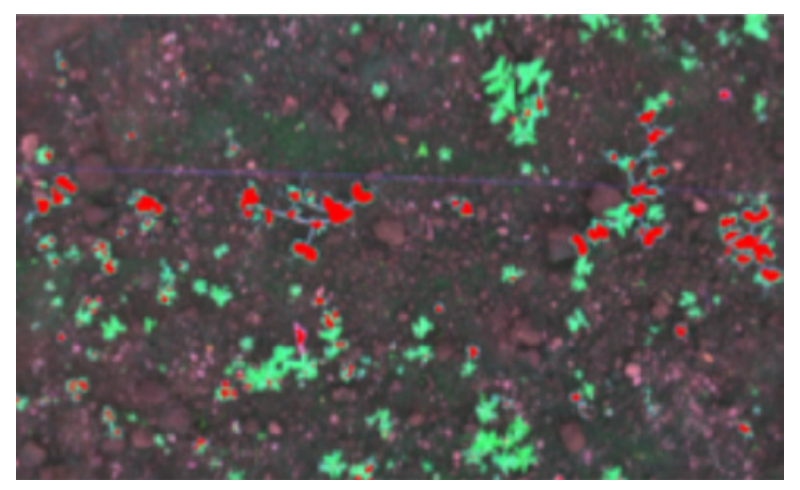

DAVID ALEJANDRO JAMAICA-TENJ01,5

ANDRES ESTEBAN PUERTO-LARA ${ }^{2}$

JHONATAN JAVIER GUERRERO-ALDANA ${ }^{1}$

OSCAR LEONARDO GARCÍA-NAVARRETE

GUSTAVO ADOLFO LIGARRETO-MORENO ${ }^{4}$

First stage image processing, pea cluster identification.

Photo: O. García; Process: A. Puerto

\begin{abstract}
In Colombia, peas are the second most important legume after the bean, and weeds are the main biotic factor that limits production, causing losses of up to $100 \%$. Manual control can represent up to $40 \%$ of the labor force. The critical period in the crop-weed competition is the first third of the crop cycle; therefore, pre-emergent herbicide applications are a cost-effective way to control weeds. Common variables for assessing weed-control efficacy include, weed density (individuals/area), which is precise but time consuming, and weed coverage (\%), which is faster but very subjective. Therefore, pre-emergence herbicides and a weed-control evaluation method that standardizes, facilitates, and provides greater precision are needed for peas cultivation and experimentation. Five pre-emergent herbicides (linuron, S-metolachlor, metribuzine, oxifluorfen and pendimetalin) were evaluated at two doses in a greenhouse pea crop. Also, two methods (quantification process of multispectral images and conventional human visual) for assessing weed coverage and control efficacy were compared. The best herbicide treatment for the dry grain yield was metribuzine ( $\left.2.36 \mathrm{t} \mathrm{ha}^{-1}\right)$. Furthermore, the effectiveness of the weed control was $88 \%$ at 36 days after sowing, which is optimal. Finally, there was
\end{abstract}

Independent Researcher, Bogota (Colombia). ORCID Jamaica-Tenjo, D.A.: 0000-0003-4331-8716;

ORCID Guerrero-Aldana, J.J.: 0000-0001-7814-0044

2 Fundación Universitaria Panamericana, Bogota (Colombia). ORCID Puerto-Lara, A.E.: 0000-0002-3818-5667

3 Universidad Nacional de Colombia, Facultad de Ingeniería, Bogota (Colombia). ORCID García-Navarrete, O.L.: 0000-0001-5075-460X

4 Universidad Nacional de Colombia, Facultad de Ciencias Agrarias, Bogota (Colombia). ORCID Ligarreto-Moreno, G.A.: 0000-0001-9372-6094

5 Corresponding author. dajamaicat@gmail.com 
agreement between the weed assessment methods (human vs. machine). The intraclass correlation coefficient was over 0.95 , which validates the use of machine quantification for weed coverage.

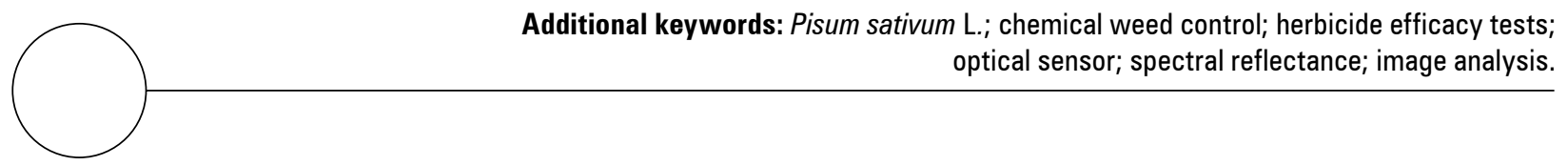

\section{RESUMEN}

En Colombia, la arveja es la segunda leguminosa más importante en superficie después del frijol, y las malezas son el principal factor biótico que limita su producción, provocando pérdidas de hasta el 100\%, y su control manual puede representar hasta el $40 \%$ de la mano de obra necesaria para su producción. El período crítico de competencia cultivo-malezas es el primer tercio del ciclo del cultivo, por lo tanto, la aplicación de herbicidas pre-emergentes es una forma rentable de control de malezas. Para evaluar la eficacia del control de malezas, las variables más comunes es la densidad de malezas (individuos/área): precisa, pero requiere mucho tiempo, o cobertura de malezas (\%): más rápida, pero muy subjetiva. Por lo tanto, encontrar herbicidas preemergentes para arveja y un método de evaluación del control de malezas que estandarice, facilite y dé mayor precisión es una tarea imperativa. Se evaluaron cinco herbicidas preemergentes (linuron, S-metolachlor, metribuzine, oxifluorfen y pendimetalin) a dos dosis en un cultivo de arvejas bajo invernadero. Además, se compararon dos métodos diferentes para evaluar la cobertura de malezas y la eficacia del control (proceso de cuantificación de imágenes multiespectrales y estimación visual humana convencional). El mejor tratamiento herbicida para el rendimiento de grano seco fue la metribuzina (2,36 $\mathrm{t}$ ha $\left.{ }^{-1}\right)$. Además, la efectividad del control de malezas fue del $88 \%$ a los 36 días después de la siembra, lo que se considera óptimo. Finalmente, se encontró concordancia entre los métodos de evaluación de malezas (humano vs. máquina). El coeficiente de correlación intraclase fue superior a 0,95 , lo que valida el uso de esta metodología de cuantificación de la cobertura de malezas.

Palabras clave adicionales: Pisum sativum L.; control químico de malezas; prueba de eficacia con herbicidas; sensor óptico; reflectancia espectral; análisis de imagen.

Received: 28-08-2020 Accepted: 19-10-2020 Published: 06-05-2021

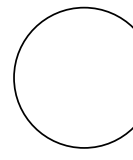

INTRODUCTION

Globally, around 21.7 million tons of peas are produced on more than 2.78 million hectares. Countries such as China and India cover $75.5 \%$ of production (FAO, 2019). In Colombia, peas are the second most important legume, after bean cultivation. Fenalce (2010) noted that production requires a significant amount of labor, generating around 15 thousand direct jobs. It is produced with greater intensity at high altitudes $>2,000 \mathrm{~m}$ a.s.l., so departments such as Nariño, Cundinamarca, Boyaca and Tolima cover more than $90 \%$ of the domestic production (Agronet, 2018).

The main biotic factors that limit production are described below. Ascochyta spp. reduces pea yield by
$10-60 \%$ through deterioration of the pod and grain, decreasing commercial value (Bretag et al., 2006). In the initial stages, pests affect crop establishment by up to $100 \%$ (Ciancio, and Mukerji, 2007). Peas are recognized as a low-competition plant that requires strict weed control (Díaz and Zapata, 1990; Zamorano et al., 2008). It also serves as a host for pests and diseases (ICA, 2012). Finally, weeds have the greatest impact on crop losses (DANE, 2015).

Weed identification and quantification is required to know weed biodiversity, to know the effect of weeds in crop yield or to know the effect of the control strategies on weeds and different objectives require different sampling strategies and several variables 
measured, such as density, which measures the number of individuals for a given area and coverage which is the percentage of area covered by weeds on the ground (Blanco and Leiva, 2010; Jamaica and Plaza, 2014).

Weed evaluation using conventional sampling methods are time consuming, so, methodologies or tools that improve these techniques in terms of efficiency and precision are needed. Several authors have observed that these conventional methods are subjective and unreliable (Andújar et al., 2010; GonzálezAndújar et al., 2011; Nkoa et al., 2015; Zimdahl, 2018). Within the framework of the fourth industrial revolution, the use of sensors and image processing can improve weed infestation assessments.

Remote sensing aims to recognize terrestrial surface characteristics, which are recorded by a sensor (Sobrino, 2000). Spectral and morphometric properties allow to detect weed populations and differentiate them from the soil and crop (Jurado-Expósito et al., 2003). The main characteristics of sensors are spectral, spatial and temporal resolution. Spectral resolution is the number of bands (nm) that sensors can get separately. Spatial resolution is the physical area that each pixel represents in the image. This area depends on the height at which the image is taken and its resolution. Finally, temporal resolution refers to the how often data of the same area is collected by sensors (Castillejo-González et al., 2014; Torres-Sánchez et al., 2015).

For example, satellites systems have low temporal resolution because they provide information every time you fly over the area of interest and low spatial resolution since they are located kilometers above the surface. In contrast, R-PAS (Remote Pilot Aircraft System) overcomes these problems because it is more frequently available and is found at a low altitude, but it is still not suitable for weed evaluations in herbicide efficacy tests since it requires a very high spatial resolution ( $\mathrm{mm} /$ pixel) and high temporal availability.

On the other hand, efficacy bioassays are essential for the evaluation process and are required for the registration of chemical pesticides for agricultural use (CPAU) in Colombia. In accordance with Decision 436 of the Andean Community of Nations (ACN), CPAU efficacy bioassays must be carried out, and the testing protocol must be presented so competent authorities can supervise the method for subsequent approval (CAN, 1998).

These efficacy bioassays are essentially the percentage of control over a pest organism under treatment as compared with an untreated area. In weeds, the most used evaluation method is visual estimation of the coverage, counts and dry mass, using squares of $0.25 \times 0.25 \mathrm{~m}$ or $0.5 \times 0.5 \mathrm{~m}$ as a sampling unit. This method must be supported by statistical analyses with sufficient repetitions, randomization and untreated areas (ANDI and ICA, 2015).

However, in Colombia, there is no record of registered pre-emergent herbicides in pea crops; however, there is a record for crops such as carrot, onion, and tomatoes, etc. (ICA, 2019). Pre-emergence herbicides are applied to the soil after planting and before crop emergence. This practice aims to mitigate the negative effect of the crop-weed competition in early crop stages (Wágner and Nádasy, 2006; Zamorano et al., 2008).

Pre-emergent herbicides were tested to control weeds in a pea crop. It was found that linuron and metribuzin, at doses of $3 \mathrm{~kg}$ and $0.75 \mathrm{~L} \mathrm{ha}^{-1}$, had 98 and $100 \%$ effectiveness (Espinoza and Ormeño, 1989). The weeds were controlled at $90 \%$ during the first 45 days after sowing (DAS) with flumozazin and acetolachlor at a dose of $150 \mathrm{~mL}$ and $1 \mathrm{~L} \mathrm{ha}^{-1}$, respectively. Lescano et al., (2017) obtained 90\% control during the first 45 DAS, and a large portion of tests with mixtures showed control over $80 \%$ under field conditions in that region. A mixture with imidazolinones is recommended (Yanniccari et al., 2017). Successful control with pendimetalin at pc $1.5 \mathrm{~kg} \mathrm{ha}^{-1}$ and fluchloralin at pc $1 \mathrm{~kg} \mathrm{ha}^{-1}$ has been reported (Rana, 2002). An herbicide combination trial of pendimethalin at pc $1 \mathrm{~kg} \mathrm{ha}^{-1}$ in pre-emergence had better weed control, but applications of imazetapir + imazamox $60 \mathrm{~g} \mathrm{ha}^{-1}$ in post-emergence ( $45 \mathrm{dds}$ ) may be an alternative for mixed weed control (Mawalia et al., 2016).

In these trials, plants were randomly sampled. The data were evaluated in conventionally (severity scales, counts and coverage). Given the shortcomings of these methods, new ones are needed for assessing weed control effectiveness using emerging technologies framed in the fourth industrial revolution. Therefore, the objective was to evaluate different pre-emergent herbicides and doses in a pea crop and validate the use of multispectral images, since remote sensing of weed infestations can be more precise and 
may allow site specific weed management in order to reduce herbicide use by up to $70 \%$ (Weis and Sökefeld, 2010).

\section{MATERIALS AND METHODS}

Peas of the Vizcaya variety were sown in the greenhouses of the Faculty of Agricultural Sciences of the Universidad Nacional de Colombia, Bogota campus. The treatments were tested using a complete randomized design with two factors (herbicides and doses). The treatments consisted of an untreated area, five herbicides, and two doses level with three replications. The untreated treatment was replicated six times to obtain a balanced experimental plot. Thus, 36 experiment units $(2.0 \times 3.3 \mathrm{~m})$ were established (Tab. 1).

Weed presence, in terms of soil cover percentage at 12, 24 and 36 DAS, was assessed with two methods: conventional human visual estimation and multispectral images. In the former, the data were obtained by a person who was an expert. In the latter, a Parrot Sequoia ${ }^{\circledR}$ multispectral sensor, mounted in a frame, took images at $1.6 \mathrm{~m}$ (Fig. 1). This height was chosen because a high spatial resolution was needed to evaluate the trial and only one image was needed for each experiment unit. The sensor used a camera with $16 \mathrm{Mpx}$ RGB and spatial resolution of $0.22 \mathrm{~cm}^{2}$ per pixel at $2 \mathrm{~m}$, with four monochromatic bands: red $(660 \mathrm{~nm})$, green $(550 \mathrm{~nm})$, near-red $(735 \mathrm{~nm})$ and near infrared $(790 \mathrm{~nm})$.

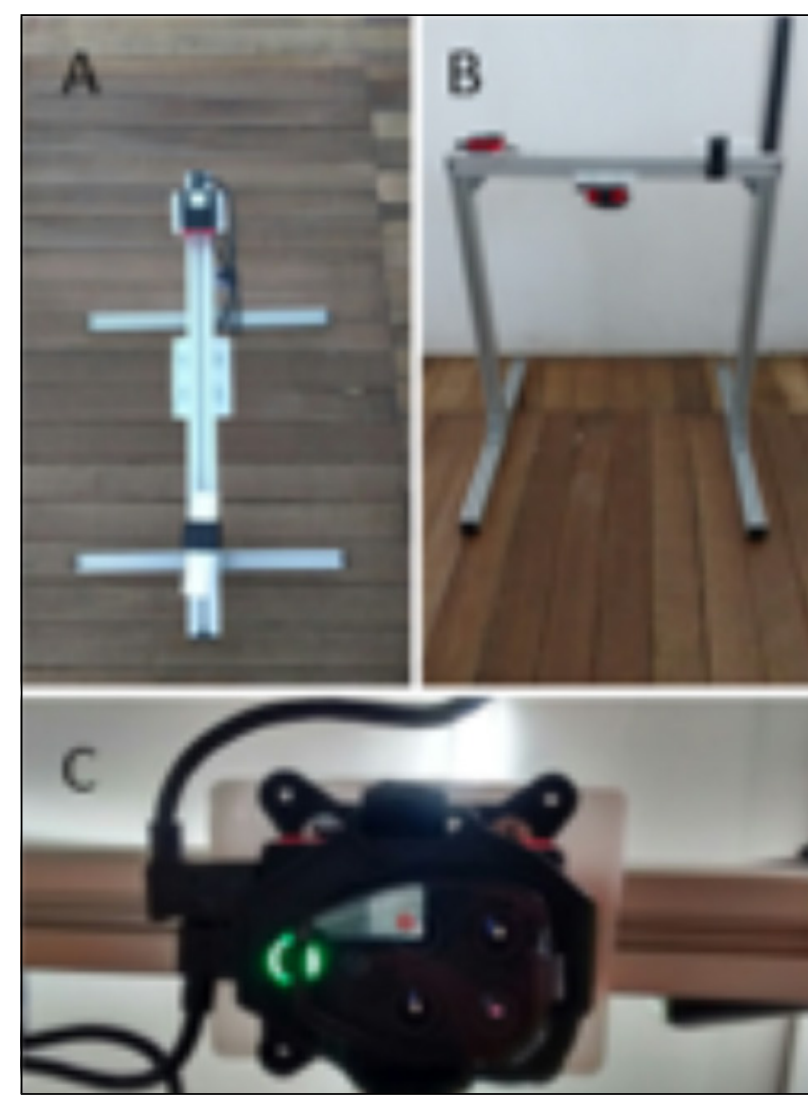

Figure 1. Small $(0.6 \mathrm{~m})$ support structure of the camera: $(A)$ Top view of the frame, (B) front view of the frame and (C) sensor adapted to the frame. Adapted from Puerto (2017).

To process the images, software was developed using an algorithm known as fuzzy C-means. This version is a modified $\mathrm{K}$-means that associates the probability

\section{Table 1. Herbicides and dose evaluated.}

\begin{tabular}{|l|c|c|c|c|c|}
\hline Herbicide & Dose level & Registered crop use (c.p.) & Units & Dose (c.p.) & Dose (a.i.) \\
\hline Linuron & DC & Carrot & $\mathrm{g} \mathrm{ha}^{-1}$ & 1,500 & 900 \\
\hline Linuron & MD & Carrot & $\mathrm{g} \mathrm{ha}^{-1}$ & 750 & 450 \\
\hline S-Metolachlor & DC & Beet & $\mathrm{mL} \mathrm{ha}^{-1}$ & 750 & 698 \\
\hline S-Metolachlor & MD ha-1 & 375 & 360 \\
\hline Metribuzine & DC & Beet & $\mathrm{mL} \mathrm{ha}^{-1}$ & 1,000 & 576 \\
\hline Metribuzine & MD & Potato & $\mathrm{mL} \mathrm{ha}^{-1}$ & 500 & 288 \\
\hline Oxifluorfen & DC & Potato & $\mathrm{mL} \mathrm{ha}^{-1}$ & 1,100 & 633.6 \\
\hline Oxifluorfen & MD & Onion & 550 & 316.8 \\
\hline Pendimetalin & DC & Onion & $\mathrm{mL} \mathrm{ha}^{-1}$ & 2,000 & 960 \\
\hline Pendimetalin & MD & Onion & $\mathrm{mL} \mathrm{ha}^{-1}$ & 1,000 & 480 \\
\hline
\end{tabular}

DC: Commercial dose; MD: half of the commercial dose; c.p: commercial product. a.i: active ingredient. 
of a pixel belonging to a certain class (Bai et al., 2017). The multispectral camera obtained false color images with the appearance of a simple RGB image; for example, a false green is shown in figure 2 .

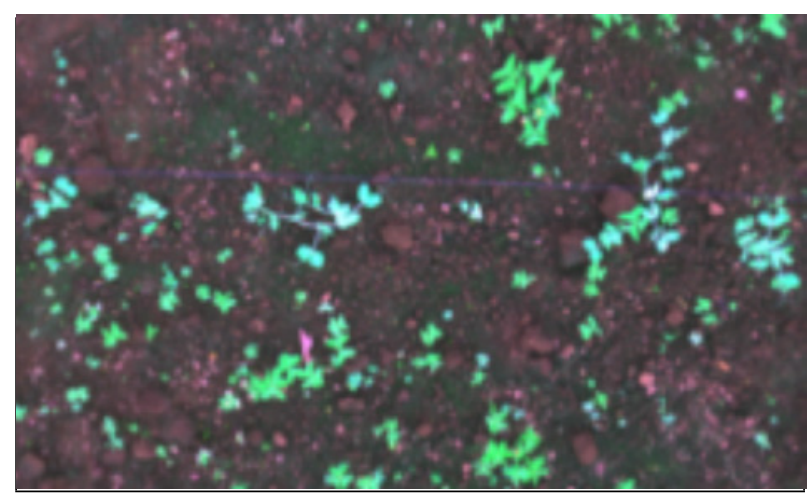

Figure 2. Multispectral image of the false green. The R, NIR and $G$ bands were used as RGB representation components (Puerto, 2017).

The fuzzy C-means algorithm is supported in the following function:

$J(U, V)=\sum_{i=1}^{c} \sum_{k=1}^{N}\left(U_{k i}\right)^{m} D\left(X_{k}, V_{i}\right)(m>1)$

where $U_{k i}$ is the probability associated to each pixel, and $D\left(X_{k}, V_{i}\right)$ is the Euclidean distance between pixel $X_{k}$ and centroid $V_{i}$.

The optimal values must be found:

$\widehat{U}=\arg \min _{u \in U} J(U, \widehat{V}) \quad \widehat{V}=\arg \min _{v \in V} J(\widehat{U}, V)$

The solution of this optimization problem yields the following result:

$$
\begin{aligned}
& \hat{u}_{k l}=\left[\sum_{j=1}^{c}\left(\frac{D\left(x_{k}, \hat{v}_{l}\right)}{D\left(x_{k}, \hat{v}_{J}\right)}\right)^{\frac{1}{m-1}}\right]^{-1} \\
& \hat{v}_{l}=\frac{\sum_{k=1}^{N}\left(\hat{u}_{k l}\right)^{m} x_{k}}{\sum_{k=1}^{N}\left(\hat{u}_{k l}\right)^{m}}
\end{aligned}
$$

The implementation of the algorithm is carried out as follows:

1. Randomly start the values $U_{k i}$.

2. Find the centroid using Eq. (4).

3. Calculate new values of $U_{k i}$.
4. Calculate the objective function of Eq. (1).

5. Repeat steps 2 to 4 until the algorithm converges.

The convergence of the algorithm depends on a minimal variation between iterations. Figure 3 shows the resulting image when figure 2 is processed.

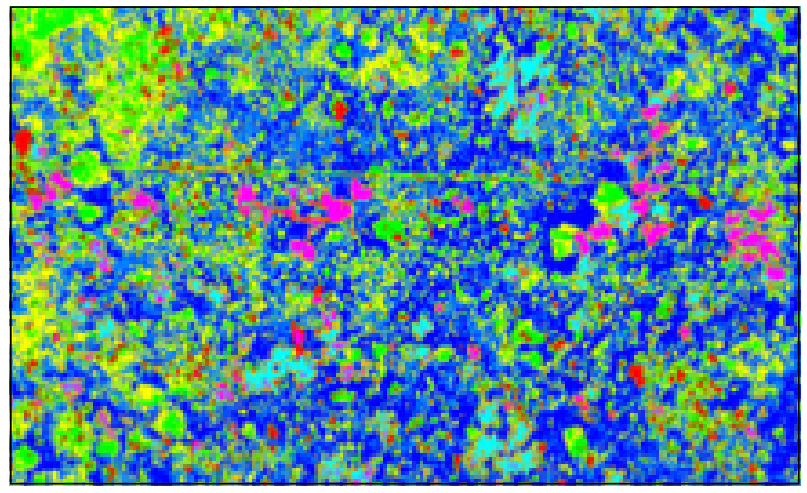

Figure 3. Result of fuzzy C-means processing.

The pea crop is denoted by the magenta pixels. Notably, the resulting image evidenced other types of objects that were less evident in the original image, especially on the ground (Puerto, 2017). Finally, the cluster of interest was transferred to the original image to demonstrate detection and subsequently find its coverage (Fig. 4).

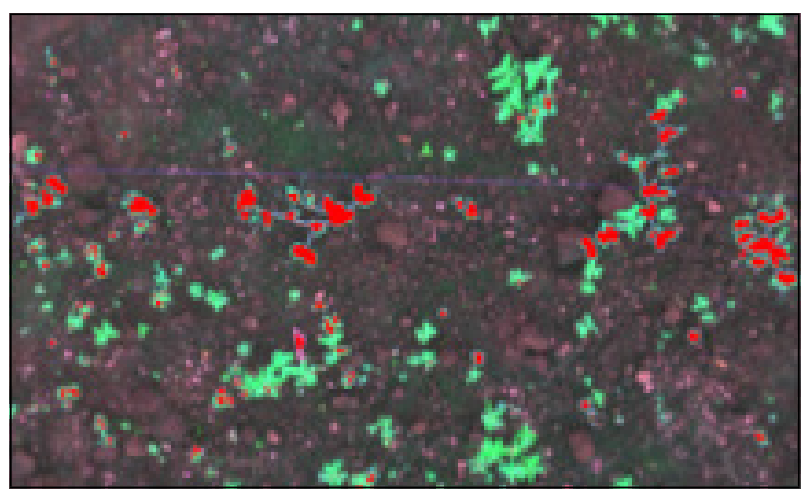

Figure 4. Detection of the pea plants on a piece of land (Puerto, 2017).

The variable coverage was transformed into efficacy by calculating the Abbott's corrected efficacy (Eq. 5), where 0 means that there was no control compared to the untreated plants, and 100 means there was control of all weeds. 


$$
E f=\left(1-\frac{T d}{C d}\right) \times 100
$$

where, $T d$ is the infestation of the treated plot after applying the treatment, and $C d$ is the infestation of the untreated plot.

A harvest sampling was also carried out in the central line of each plot. In the field, crop establishment was determined by measuring the number of plants and number of pods, and, in the laboratory, yield variables such as number of grains per pod and weight of $50 \mathrm{~g}$ were measured to determine the yield per plot in $\mathrm{tha}^{-1}$.

The yield was estimated with Eq. 6:

Yield $\left(\frac{t}{h a}\right)=\frac{\left(N P P \times P P P \times G P D \times\left(\frac{P C G}{50}\right) \times\left(\frac{10000}{A P}\right)\right)}{1000000}$

where, NPP is the number of plants per plot, PPP is the number of pods per plant, GPD is the number of grains per pod, $P C G$ is the weight of $50 \mathrm{~g}$, and AP is the area of the plot.

Finally, the statistical package $\mathrm{R}$ was used to determine statistical assumptions of normality. The analysis of variance ANOVA was applied to reveal significant differences for the pre-emergence herbicide treatments and doses. Agreement between the evaluation methods (human vs. machine) was analyzed with the Intraclass Correlation Coefficient (ICC) in the "irr" package (Gamer et al., 2010), as recommended by Andújar et al. (2010), and configured to a "one-way" model, "single" unit, and the BlandAltman plot to determine agreement between both data sets.

\section{RESULTS AND DISCUSSION}

In the experimental plot, the floristic composition had $90 \%$ coverage by broadleaf species and $10 \%$ by narrow leaf species (grasses) (Tab. 2).

Table 2. Weed species found in the experimental plot.

\begin{tabular}{|l|l|}
\hline \multicolumn{1}{|c|}{ Group } & \multicolumn{1}{|c|}{ Species } \\
\hline Broadleaves & $\begin{array}{l}\text { Sonchus oleraceus L., Oxalis corniculata L., Stellaria } \\
\text { media L., Capsella bursa-pastoris L., Trifolium repens L. }\end{array}$ \\
\hline Grasses & Poa annua L. \\
\hline
\end{tabular}

When comparing the two weed coverage estimation methods, the ICC was 0.967 with a p-value of 0 , which showed excellent agreement between the methods, meaning that one could replace the other (Giavarina, 2015; Osorio et al., 2020). In the BlandAltman plot, the X-axis represented the means of coverage, while the Y-axis represented the difference between the methods. Black lines represent the confidence limits of the methods (Fig. 5), which fall within the range of acceptable tolerance limits (-12 to +17 ), which is acceptable but depends on the use of the data and the sensitivity of the bias. The blue line was obtained with the values estimated with the regression model. The negative slope was interpreted as an overestimation of coverages of conventional human visual estimation versus the multispectral image procedure (Osorio et al., 2020), similar to the results of Benlloch et al. (1996) despite the older image processing methods.

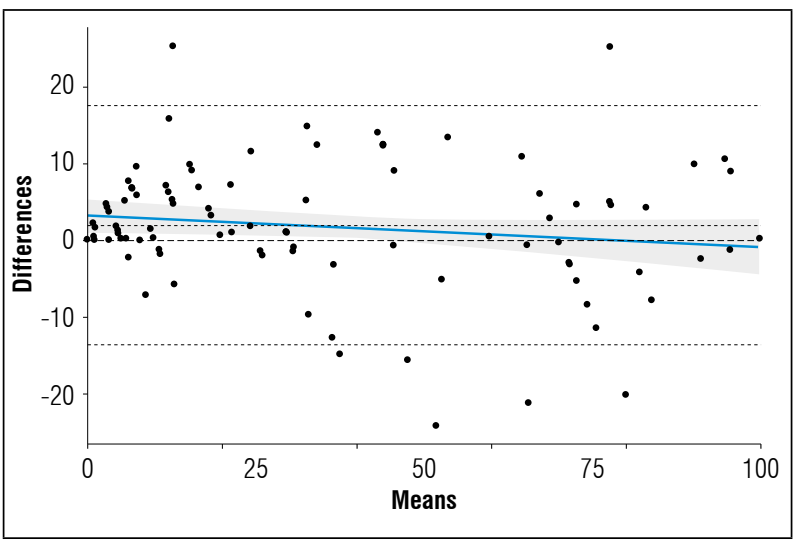

Figure 5. Validation of the weed coverage evaluation method.

The corresponding analysis for data recorded at 36 DAS (Tab. 3) compared the treatment means with the Tukey test (Fig. 6). The ANOVA showed differences between the treatments for weed control. There were no differences for the doses, and there was no significant interaction between the herbicides and doses. The Tukey test for the treatments indicated that oxifluorfen and metribuzin had the highest efficacy; that Linuron did not have adequate control of the weeds, similar to the results of (Banga et al., 1998), and that metolachlor and pendimethalin (recommended for grass control) did not control the weeds. The latter was explained by a large presence of broader leaves in the treated plots. The data at 12 and 24 DAS are not shown because they did not differ from the data at 36 DAS. 
Table 3. ANOVA for herbicide efficacy data recorded at 36 DAS.

\begin{tabular}{|l|c|c|c|c|c|}
\hline & Df & Sum Sq & Mean Sq & F value & $P(>F)$ \\
\hline Herbicide & 5 & 52793 & 10559 & 80.951 & $3.17 \cdot 10^{-14}$ \\
\hline Dose & 1 & 9 & 9 & 0.068 & 0.796 \\
\hline Herbicide×Dose & 5 & 296 & 59 & 0.453 & 0.807 \\
\hline Residuals & 24 & 3130 & 130 & & \\
\hline
\end{tabular}

Df: degrees of freedom; sq: squares.

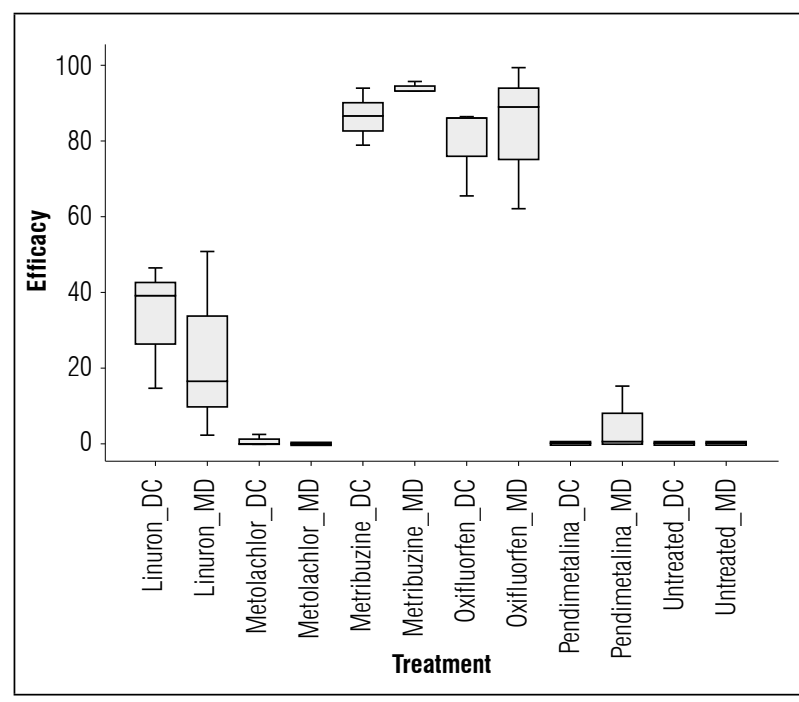

Figure 6. Herbicide efficacy at 36 DAS. Statistical differences between two groups: orange (good control) and green (poor control). DC: full commercial dose; MD: half of the commercial dose, see table 1.

Previously, the herbicides with the best efficacy were reported as metribuzine and oxifluorfen. However, as shown in figure 7 , the crop establishment for oxifluorfen did not exceed $67 \%$, with yield like that obtained with the herbicides linuron, metolachlor at medium dose, and pendimethalin. Tests carried out by Semidey and Almodóvar (1987) showed that, with a commercial dose of $0.6 \mathrm{~L}^{\text {ha }}{ }^{-1}$ of a.i., Cajanus cajan has phytotoxicity that disappears in 9 weeks, without altering yield.

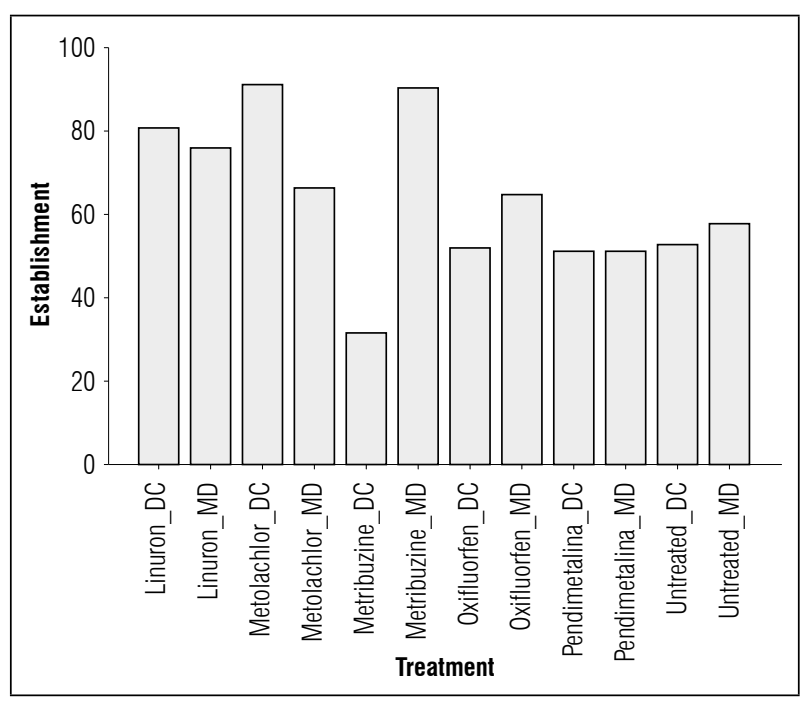

Figure 7. Crop establishment (\%) at 36 DAS. DC: full commercial dose; MD: half of the commercial dose, see table 1.

There was interaction between the treatment and dose for yield (Tab. 4.) since the metribuzine doses had the biggest difference. At an a.i. dose of $0.6 \mathrm{~L} \mathrm{ha}^{-1}$, $33 \%$ establishment was reached, with a yield of 0.13 t ha ${ }^{-1}$ (the lowest). The $0.3 \mathrm{~L} \mathrm{ha}^{-1}$ dose reached $90 \%$ establishment, with a yield of $2.37 \mathrm{t} \mathrm{ha}^{-1}$ (the highest). At 36 DAS, a control efficacy of $88 \%$ of the weed cover was achieved, which was the optimal result and the treatment recommended by this assay (Fig. 8). This contrasting result may have been due to the loss of selectivity of the herbicide to the crop from

Table 4. ANOVA for grain yield $\left(\mathrm{t} \mathrm{ha}^{-1}\right)$ by treatments, dose and interaction.

\begin{tabular}{|l|c|c|c|c|c|}
\hline & Df & Sum Sq & Mean Sq & F value & P(>F) \\
\hline Herbicide & 5 & 4.62 & 0.924 & 4.311 & 0.00611 \\
\hline Dose & 1 & 1.319 & 1.3189 & 6.153 & 0.02053 \\
\hline Herbicide x Dose & 5 & 7.069 & 1.4138 & 6.597 & 0.00054 \\
\hline Residuals & 24 & 5.143 & 0.2143 & & \\
\hline
\end{tabular}

Df: degrees of freedom; sq: squares 
the dose. Wágner and Nádasy (2006) tested this herbicide at higher doses, finding similar results.

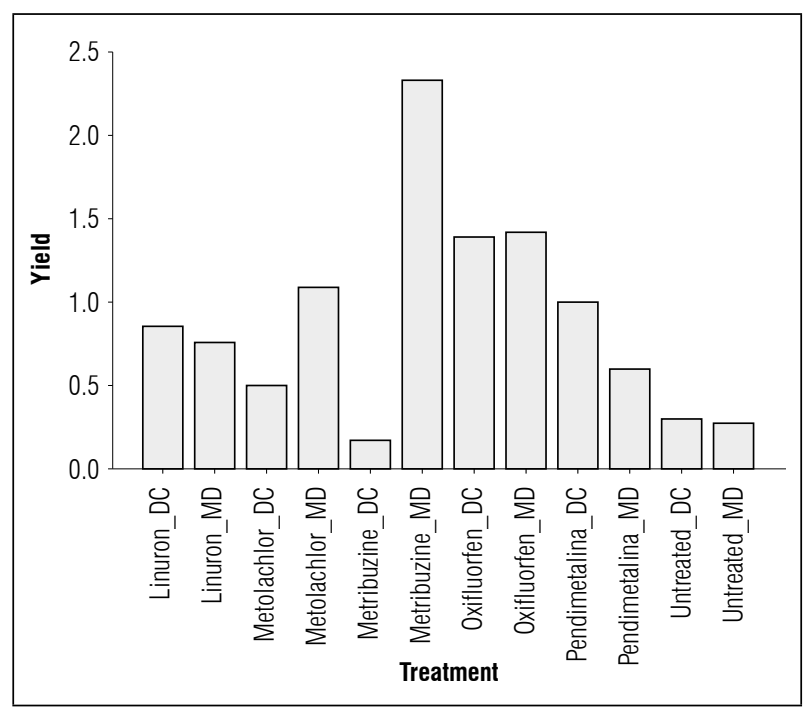

Figure 8. Estimated yield for each treatment $\left(\mathbf{t ~ h a}{ }^{-1}\right)$. DC: full commercial dose; MD: half of the commercial dose, see table 1.

\section{CONCLUSION}

The weed coverage assessment with sensor and image processing was validated and had contrasting advantages over the conventional visual-human method since it was faster and more precise. This methodology can be used to standardize coverage samples for herbicide efficacy tests, especially for register trials. Further studies could fully assess the economic advantages of using this technology.

The Metribuzine application at $\mathrm{MD}$ was the best treatment for controlling weeds, obtaining the highest crop establishment and grain yield. Further studies could find the adequate doses since $\mathrm{MD}$ (half of commercial dose) was enough to control the weeds.

Metolachlor and Pendimethalin were not effective at controlling the weeds because of the predominance of broad leaves in the pea crop. Oxyfluorfen had the highest efficacy for weed control but also had the greatest phytotoxic effect on the pea plants; therefore, it is not recommended as a pre-emergence treatment in pea cropping systems.

Linuron was ineffective for controlling the weeds probably because the tested doses were low.
Conflict of interests: The manuscript was prepared and reviewed with the participation of the authors, who declare that there exists no conflict of interest that puts at risk the validity of the presented results.

\section{BIBLIOGRAPHY REFERENCES}

Agronet. 2018. Evaluaciones agropecuarias municipales. In: https://www.agronet.gov.co/estadistica/Paginas/ home.aspx?.cod=1\#; consulted: October, 2020.

ANDI, Asociación Nacional de Empresarios de Colombia; ICA, Instituto Colombiano Agropecuario. 2015. Manual para elaboración de protocolos para ensayos de eficacia con PQUA. In: https://www.ica.gov.co/ areas/agricola/servicios/regulacion-y-control-de-plaguicidas-quimicos/manual-protocolos-ensayos-eficacia-pqua-1.aspx; consulted: October, 2020.

Andújar, D., A. Ribeiro, R. Carmona, C. Fernández-Quintanilla, and J. Dorado. 2010. An assessment of the accuracy and consistency of human perception of weed cover. Weed Res. 50(6), 638-647. Doi: 10.1111/j.1365-3180.2010.00809.x

Bai, X., X. Li, Z. Fu, X. Lv, and L. Zhang. 2017. A fuzzy clustering segmentation method based on neighborhood grayscale information for defining cucumber leaf spot disease images. Comput. Electron. Agric. 136, 157165. Doi: 10.1016/j.compag.2017.03.004

Banga, R.S., A. Yadav, R.S. Malik, and R.K. Malik. 1998. Evaluation of different herbicides for weed control in pea. Indian J. Weed Sci. 30(3-4), 145-148.

Benlloch, J., A. Sánchez-Salmerón, S. Christensen, and M. Walter. 1996. Weed mapping in cereal crops using image analysis techniques. pp. 1059-1060. In: Proc. $3^{\text {rd }}$ International Conference on Precision Agriculture. Minneapolis, $\mathrm{MN}$.

Blanco, Y. and A. Leiva. 2010. Abundancia y diversidad de especies de arvenses en el cultivo de maíz (Zea mays, L.) precedido de un barbecho transitorio después de la papa (Solanum tuberosum L.). Cultivos Tropicales 31(2), 12-16.

Bretag, T.W., P.J. Keane, and T.V. Price. 2006. The epidemiology and control of ascochyta blight in field peas: a review. Aust. J. Agric. Res. 57(8), 883. Doi: 10.1071/ AR05222

CAN, Comisión de la Comunidad Andina. 1998. Decisión 436, Norma Andina para el Registro y Control de Plaguicidas Químicos de Uso Agrícola. GO 347. Cartagena, Colombia.

Castillejo-González, I., J.M. Peña-Barragán, M. Jurado-Expósito, F. Mesas-Carrascosa, and López-Granados. 2014. Evaluation of pixel- and object-based approaches for mapping wild oat (Avena sterilis) weed patches in wheat fields using QuickBird imagery for site-specific 
management. Eur. J. Agron. 59, 57-66. Doi: 10.1016/j. eja.2014.05.009

Ciancio, A. and K.G. Mukerji (eds.). 2007. General concepts in integrated pest and disease management. Springer, Dordrecht, The Netherlands.

DANE, Departamento Administrativo Nacional de Estadística of Colombia. 2015. Insumos y factores asociados a la producción agropecuaria: el cultivo de arveja. Boletín Mensual 33. Bogota.

Díaz, J. and M. Zapata. 1990. Control de malezas: práctica agronómica fundamental en el cultivo de la arveja. Investigación y Progreso Agropecuario Carillanca 9(4), 28-33.

Espinoza, N. and J. Ormeño. 1989. Las malezas en arveja y su control. Serie Carillanca. INIA. Temuco, Chile.

FAO. 2019. FAOSTAT - Data Crops In: http://www.fao. org/faostat/en/\#data/OC; consulted: May, 2021.

Fenalce, Federación Nacional de Cultivadores de Cereales, Leguminosas y Soya of Colombia. 2010. El cultivo de la arveja, historia e importancia. Bogota.

Gamer, M., J. Lemon, I. Fellows, and P. Singh. 2010. Various coefficients of interrater reliability and agreement. Version 0.84.1. In: https://rdrr.io/cran/irr/; consulted: October, 2020.

Giavarina, D. 2015. Understanding bland altman analysis. Biochem. Med. 25(2), 141-151. Doi: 10.11613/ BM.2015.015

González-Andújar, J.L., C. Fernández-Quintanilla, F. Bastida, R. Calvo, J. Izquierdo, and J. Lezaun. 2011. Assessment of a decision support system for chemical control of annual ryegrass (Lolium rigidum) in winter cereals. Weed Res. 51(3), 304-309. Doi: 10.1111/j.1365-3180.2011.00842.x

ICA, Instituto Colombiano Agropecuario. 2012. Manejo fitosanitario del cultivo de hortalizas - Medidas para la temporada invernal. Bogota.

ICA, Instituto Colombiano Agropecuario. 2019. Registros nacionales PQUA - Palguicidas registrados 2019. Retrieved from https://www.ica.gov.co/; consulted: October, 2020.

Jamaica, D. and G. Plaza. 2014. Evaluation of various conventional methods for sampling weeds in potato and spinach crops. Agron. Colomb. 32(1), 36-43. 10.15446/ agron.colomb.v32n1.39613

Jurado-Expósito, M., F. López-Granados, S. Atenciano, L. García-Torres, and J.L. González-Andújar. 2003. Discrimination of weed seedlings, wheat (Triticum aestivum) stubble and sunflower (Helianthus annuus) by near-infrared reflectance spectroscopy (NIRS). Crop Prot. 22(10), 1177-1180. Doi: 10.1016/ S0261-2194(03)00159-5

Lescano, M.C., D. Faccini, E. Puricelli, and A. Nicolari. 2017. Evaluación de la eficacia de distintos herbicidas preemergentes selectivos para cultivos de soja y maíz en Chloris virgata. Agromensajes (August), 5-7.

Mawalia, A.K., S. Kumar, and S.S. Rana. 2016. Herbicide combinations for control of complex weed flora in garden pea. Indian J. Weed Sci. 48(1), 48-52. Doi: 10.5958/0974-8164.2016.00011.3

Nkoa, R., M.D.K. Owen, and C.J. Swanton. 2015. Weed abundance, distribution, diversity, and community analyses. Weed Sci. 63(Sp1), 64-90. Doi: 10.1614/ WS-D-13-00075.1

Osorio, K., A. Puerto, C. Pedraza, D. Jamaica, and L. Rodríguez. 2020. A deep learning approach for weed detection in lettuce crops using multispectral images. AgriEngineering 2(3), 471-488. Doi: 10.3390/ agriengineering2030032

Puerto, A. 2018. Clasificación y cuantificación de maleza en cultivos de hortalizas por medio de procesamiento de imágenes digitales multiespectrales. MSc thesis. Faculty of Engineering. Universidad Nacional de Colombia, Bogota.

Rana, S. 2002. Integrated weed management in pea (Pisum sativum L.) under Sangla valley conditions of Himachal Pradesh. Indian J. Weed Sci. 34(3-4), 204-207.

Semidey, N. and L. Almodóvar. 1987. Oxyfluorfen: A candidate herbicide for weed control in pigeon peas. J. Agr. U. Puerto Rico 71(3), 277-285.

Sobrino, J.A. 2000. Teledetección. Servicio de publiaciones-Universitat de València, Valencia, Spain.

Torres-Sánchez, J., F. López-Granados, and J.M. Peña. 2015. An automatic object-based method for optimal thresholding in UAV images: Application for vegetation detection in herbaceous crops. Comput. Electron. Agric. 114, 43-52. Doi: 10.1016/j.compag.2015.03.019

Wágner, G. and E. Nádasy. 2006. Effect of pre-emergence herbicides on growth parameters of green pea. Commun. Agric. Appl. Biol. Sci. 71(3 Pt A), 809-813.

Weis, M. and M. Sökefeld. 2010. Detection and identification of weeds. pp. 119-134. In: Oerke, E.C., R. Gerhards, G. Menz, and R. Sikora (eds.). Precision crop protection: the challenge and use of heterogeneity. Springer, Dordrecht, The Netherlands. Doi: 10.1007/978-90-481-9277-9_8

Yanniccari, M.E., C.M. Appella, and C.M. Istilart. 2017. Evaluación de tratamientos pre-emergentes para el control de malezas en el cultivo de arveja. Actualización Técnica de Cultivos 5(1), 108-109.

Zamorano, C., H. López, and G. Alzate. 2008. Evaluación de la competencia de arvenses en el cultivo de arveja (Pisum sativum) en Fusagasugá, Cundinamarca (Colombia). Agron. Colomb. 26(3), 443-450.

Zimdahl, R. 2018. Fundamentals of weed science. $5^{\text {th }}$ ed. Academic Press, Burlington, MA. Doi: 10.1016/ B978-0-12-811143-7.01001-5 